\title{
microRNA-145 inhibits cell proliferation, migration and invasion by targeting matrix metallopeptidase- 11 in renal cell carcinoma
}

\author{
DEYAO WU ${ }^{1 *}$, MIN LI $^{1 *}$, LINMAO WANG $^{2}$, YUNFENG ZHOU ${ }^{1}$, JIAN ZHOU ${ }^{1}$, HUIXING PAN ${ }^{1}$ and PING QU ${ }^{1}$ \\ Departments of ${ }^{1}$ Urology and ${ }^{2}$ Thoracic Surgery, The Fourth Affiliated Hospital of Nantong Medical College, \\ Yancheng City No. 1 People's Hospital, Yancheng, Jiangsu 224001, P.R. China
}

Received September 23, 2013; Accepted March 17, 2014

DOI: $10.3892 / \mathrm{mmr} .2014 .2149$

\begin{abstract}
RNA-145 (miR-145) has been reported to be frequently downregulated in various types of cancer, including renal, prostate, bladder, lung and colon cancer, as well as B-cell malignancies. The present study examined the effects of miR-145 on the cell proliferation, migration and invasion of renal cell carcinoma (RCC). Following transfection of miR-145, an MTT, cell migration, cell invasion and luciferase assays, and western blot analysis were conducted in RCC cell lines. The present study demonstrated that miR-145 inhibited cell proliferation, migration and invasion in 786-O and A498 cells. The present study also demonstrated for the first time, to the best of our knowledge, that miR-145 may directly target matrix metallopeptidase-11 (MMP-11) in RCC. miR-145 was demonstrated to suppress cell proliferation, migration and invasion by targeting MMP-11 in RCC cell lines. These results suggested that it may be investigated as a predictive marker for the early detection of tumor metastasis and for targeting therapeutic drugs to inhibit the invasion of RCC.
\end{abstract}

\section{Introduction}

Renal cell carcinoma (RCC) is a kidney cancer that originates from the proximal convoluted tubule. It represents the leading cause of mortality among urological malignancies $(1,2)$. It is the 10 th most common type of cancer in Europe (3). In the United States, there are $\sim 65,000$ novel cases and almost 14,000 mortalities from RCC annually (4). RCC includes several different histological subtypes that possess distinct biological behaviors and prognoses. The

Correspondence to: Professor Ping Qu, Department of Urology, The Fourth Affiliated Hospital of Nantong Medical College, Yancheng City No. 1 People's Hospital, 15 Yuehe Road, Yancheng, Jiangsu 224001, P.R. China

E-mail: luqiang0405@163.com

*Contributed equally

Key words: renal cell carcinoma, matrix metallopeptidase-11, microRNA-145 most common type of RCC is clear cell RCC (ccRCC), which originates in the lining of the proximal renal tubule, representing $>75-80 \%$ of all cases of RCC (5). Approximately $30 \%$ of patients have metastatic disease when diagnosed with RCC and radical nephrectomy remains the main treatment for RCC patients due to resistance to radiation and chemotherapy (6). Although the overall survival rate is $>60 \%$ over 5 years, $\sim 30 \%$ of patients with a diagnosis of localized RCC develop metastatic recurrence $(7,8)$. Patients with metastatic RCC face a poor prognosis and have limited therapeutic options. The median survival rate in a recent cohort was only 1.5 years with $<10 \%$ of patients surviving to 5 years (9). The histological grade combined with clinical stage, which is considered to be the gold standard method for the prediction of patient prognosis, is not accurate when used alone (10). Thus, molecular markers and novel treatments are required in order to improve the prognosis for patients with RCC.

MicroRNAs (miRNAs) are a class of naturally occurring, endogenous small non-coding RNA, in the size range of 19-25 nt. miRNAs regulate gene expression at the post-transcriptional level by binding through partial sequence homology, to the 3' untranslated region (3'UTR) of mammalian target mRNAs and causing translational inhibition and/or mRNA degradation (11). Since they were initially described almost 20 years ago, there has been a steady increase in their identification and the latest Release 20 of miRBase has 24,521 entries of miRNAs from various species, including 734 mature miRNAs from Gallus gallus (12). It has been predicted that as many as $30 \%$ of protein-encoding genes may be regulated by miRNAs and they may function as oncogenes and tumor suppressors (13). Upregulated miRNAs in cancer may function as oncogenes by negatively regulating tumor suppressors. By contrast, downregulated miRNAs may normally function as tumor suppressor genes and inhibit cancer by regulating oncogenes $(14,15)$. It has demonstrated the important roles of miRNAs in regulating various cellular functions, including cell apoptosis, cell proliferation, neural development and stem cell differentiation $(16,17)$. Recently, miRNAs have also been revealed to be important in tumorigenesis, cancer invasion and metastasis (18).

miR-145 has been reported to be frequently downregulated in various types of cancer, including renal, prostate, bladder, lung and colon cancer, as well as B-cell malignancies. However, the functions of miR-145 are yet to be investigated 
in RCC. The present study focused on the functions and direct target of miR-145 in RCC.

\section{Materials and methods}

Cells and culture conditions. The human ccRCC-derived cell lines 786-O and A498 were obtained from the Shanghai Institute of Cell Biology, Chinese Academy of Sciences (Shanghai, China). The cells were incubated in RPMI-1640 (HyClone Laboratories, Inc., Logan, UT, USA) or Dulbecco's modified Eagle's medium (DMEM; Gibco-BRL, Carlsbad, CA, USA) supplemented with $10 \%$ heat-inactivated fetal calf serum, $100 \mathrm{U} / \mathrm{ml}$ penicillin and $100 \mathrm{mg} / 1$ streptomycin at $37^{\circ} \mathrm{C}$ in a humidified atmosphere containing $5 \% \mathrm{CO}_{2}$.

Transfection of miR-145 mimics, scrambled control $(N C)$ and luciferase reporter plasmid. Mature miR-145 mimics, the NC and the luciferase reporter plasmid were designed and synthesized by GenePharma (Shanghai, China). The sequence of miR-145 mimics was 5'-GUCCAGUUUUCC CAGGAAUCCCU-3'. The sequence of NC mimics was 5'-UUCUCCGAACGUGUCACGUTT-3'. The insertion fragment was confirmed by DNA sequencing. Cell transfection and cotransfection were performed using Lipofectamine 2000 (Invitrogen Life Technologies) according to the manufacturer's instructions.

Cell viability assay. The cell proliferation was determined by the MTT assay. The cells transfected with miR-145 mimics or the NC were seeded in 96-well plates at a density of 3,000 cells per well. Cell proliferation was documented every $24 \mathrm{~h}$ for five days according to the manufacturer's instructions. Briefly, MTT solution was added into each well and incubated at $37^{\circ} \mathrm{C}$ for $4 \mathrm{~h}$. The plates were spun $(200 \mathrm{x}$ g for $10 \mathrm{~min})$, and the purple colored precipitates of formazan were dissolved in $200 \mu$ l dimethylsulfoxide. Absorbance (optical density, OD) was measured at $490 \mathrm{~nm}$ using an automatic multi-well spectrophotometer (Bio-Rad, Richmond, CA, USA). There were six replicate wells for every time point in each group. The suppression rate was calculated using the formula: Suppression rate $=\left(1-\mathrm{OD}_{\mathrm{miR}-145} / \mathrm{OD}_{\mathrm{miR}-\mathrm{NC}}\right) \times 100 \%$. All the experiments were performed in triplicate.

Cell migration and invasion assay. Cell motility was measured using $8 \mu \mathrm{m}$-pore polycarbonate membrane Boyden chambers inserted in a transwell apparatus (Costar, Cambridge, MA, USA). The transfected cells (miR-145 mimics and NC) growing in the log phase were treated with trypsin/EDTA solution, washed once with serum-containing RPMI-1640 medium, centrifuged (200 x g for $10 \mathrm{mins}$ ), and re-suspended as single-cell solutions. A total of $1 \times 10^{5}$ cells in $0.2 \mathrm{ml}$ serum-free RPMI-1640 medium were seeded on a transwell apparatus (Costar). RPMI-1640 (600 $\mu \mathrm{l})$ containing 20\% fetal bovine serum was added to the lower chamber. An invasion assay was performed by the same procedure except that the filters of the transwell chambers were coated with $30 \mu \mathrm{g}$ Matrigel (BD Biosciences, San Jose, CA, USA). After the cells were incubated for $12-24 \mathrm{~h}$ at $37^{\circ} \mathrm{C}$ in a $5 \% \mathrm{CO}_{2}$ incubator, the cells on the top surface of the insert were removed by wiping with a cotton swab. The cells that migrated to the bottom surface of the insert were fixed in $100 \%$ methanol for $2 \mathrm{~min}$, stained in $0.5 \%$ crystal violet for $2 \mathrm{~min}$, rinsed in phosphate-buffered saline and then subjected to microscopic inspection (magnification, x200; BX51WI-DPMC; Olympus, Tokyo, Japan). The values for invasion and migration were obtained by counting five fields per membrane and represent the average of three independent experiments.

Western blot analysis. The primary antibodies used in the present study, including anti-MMP-11 and anti- $\beta$-actin were products of Bioworld Technology (St. Louis Park, MN, USA). The total protein of cells was prepared using RIPA lysis buffer. The protein concentration in the resulting lysate was determined using the bicinchoninic acid protein assay (Beyotime Institute of Biotechnology, Shanghai, China). Equal quantities of protein were loaded onto SDS-PAGE and transferred onto polyvinylidene difluoride membranes. Following inhibition with 5\% degreased milk in Tris-buffered saline with Tween-20 (TBST; containing $0.1 \%$ Tween-20), the membranes were incubated overnight with the appropriate primary antibody. The membranes were then washed and incubated with the corresponding horseradish peroxidase-conjugated secondary antibody (goat anti-rabbit) at 1:1,000 dilution in TBST. The blot was developed with enhanced chemiluminescence solution (Pierce Biotechnology, Inc., Rockford, IL, USA) and images were captured by a FluorChem imaging system (Alpha Innotech, San Leandro, CA, USA). The intensity of each spot was read and analyzed using AlphaEaseFC software (Alpha Innotech, San Leandro, CA, USA). $\beta$-actin was used as a loading control.

Luciferase assay. The cells were plated in a 12 -well plate at $\sim 90 \%$ confluence and transfected with $0.5 \mu \mathrm{g}$ reporter plasmid, $40 \mathrm{nmol}$ miR-145 mimics or their negative control by Lipofectamine 2000. Each sample was also cotransfected with $0.05 \mu \mathrm{g}$ pRL-CMV plasmid expressing Renilla luciferase (Promega Corporation, Madison, WI, USA) as an internal control for transfection efficiency. The cells were harvested with passive lysis buffer, a component of the Dual-Luciferase Reporter Assay system (Tecan, Theale, UK), 48 h after transfection according to the manufacturer's instructions. An appropriate volume of cell lysate was added to a well of the F96 MicroWell Plates, followed by $25 \mu 1$ Luciferase Assay Reagent II (Tecan). Firefly luciferase activities and Renilla luciferase activities were measured using a luminometer (Tecan). Firefly luciferase activity was normalized to Renilla luciferase activity for each transfected well. Each assay was replicated three times.

Statistical analysis. Data are presented as the mean \pm standard deviation and compared using Student's t-test in Stata 10.0 (College Station, TX, USA). Double-tailed $\mathrm{P}<0.05$ was considered to indicate a statistically significant difference.

\section{Results}

miR-145 suppresses cell proliferation in RCC cell lines. To measure the effect of miR-145 on cell proliferation, an MTT assay was used. As shown in Fig. 1, the upregulation of miR-145 significantly inhibited cell proliferation. MTT assays revealed 

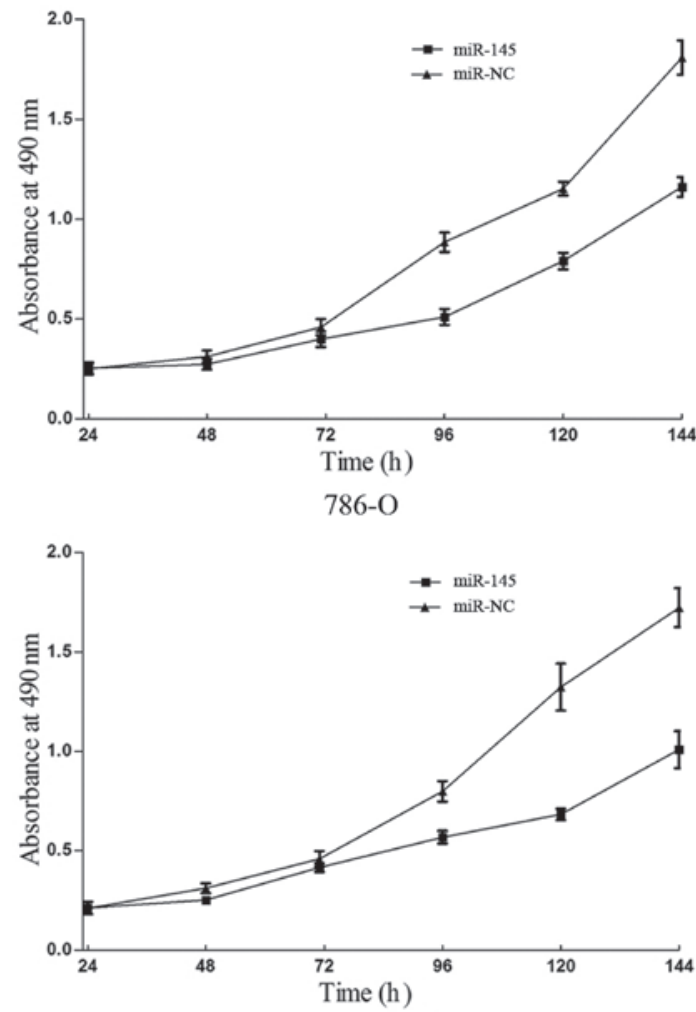

A498

Figure 1. Viability of 786-O and A498 cells following transfection of miR-145. The cell proliferation was determined by an MTT assay. The results indicated that the upregulation of miR-145 significantly suppressed cell proliferation. miR-145, microRNA-145; NC, scrambled control.

that following $144 \mathrm{~h}$ of treatment, the suppression rate of miR-145 reached $35.81 \% \pm 4.1 \%$ in $786-\mathrm{O}$ cells and $41.15 \pm 3.5 \%$ in A498 cells. These results indicated that miR-145 may be important in 786-O and A498 cells.

miR-145 inhibits cell migration and invasion in RCC cell lines To measure the effect of miR-145 on tumor cell migration and invasion, the transwell apparatus assay was used (Fig. 2). The transfected cells (miR-145 mimics and NC mimics) growing in the log phase were collected and cultured on transwell apparatus. Following $12 \mathrm{~h}$ incubation, cell migration was significantly decreased in the miR-145 groups compared with the control group $(\mathrm{P}<0.05)$. Using transwell apparatus pre-coated with Matrigel, the effects of miR-145 on cell invasiveness were examined. Following $24 \mathrm{~h}$ incubation, miR-145 transfected cells demonstrated significantly decreased invasiveness compared with the control cells $(\mathrm{P}<0.05)$. These results indicated that miR-145 inhibited cell migration and invasion in RCC cell lines.

miR-145 suppresses the expression of MMP-11 in RCC cell lines. Sachdeva et al revealed that miR-145 was able to target multiple metastasis related genes, including MMP-11 and ADAM-17 (19). Western blot analysis was performed to examine whether the protein level of MMP-11 was decreased following the transfection of miR-145. As shown in Fig. 3, MMP-11 was significantly decreased in 786-O and A498 cell lines $72 \mathrm{~h}$ after transfection of miR-145. Thus, miR-145 reduces the protein level of MMP-11 in RCC cells.
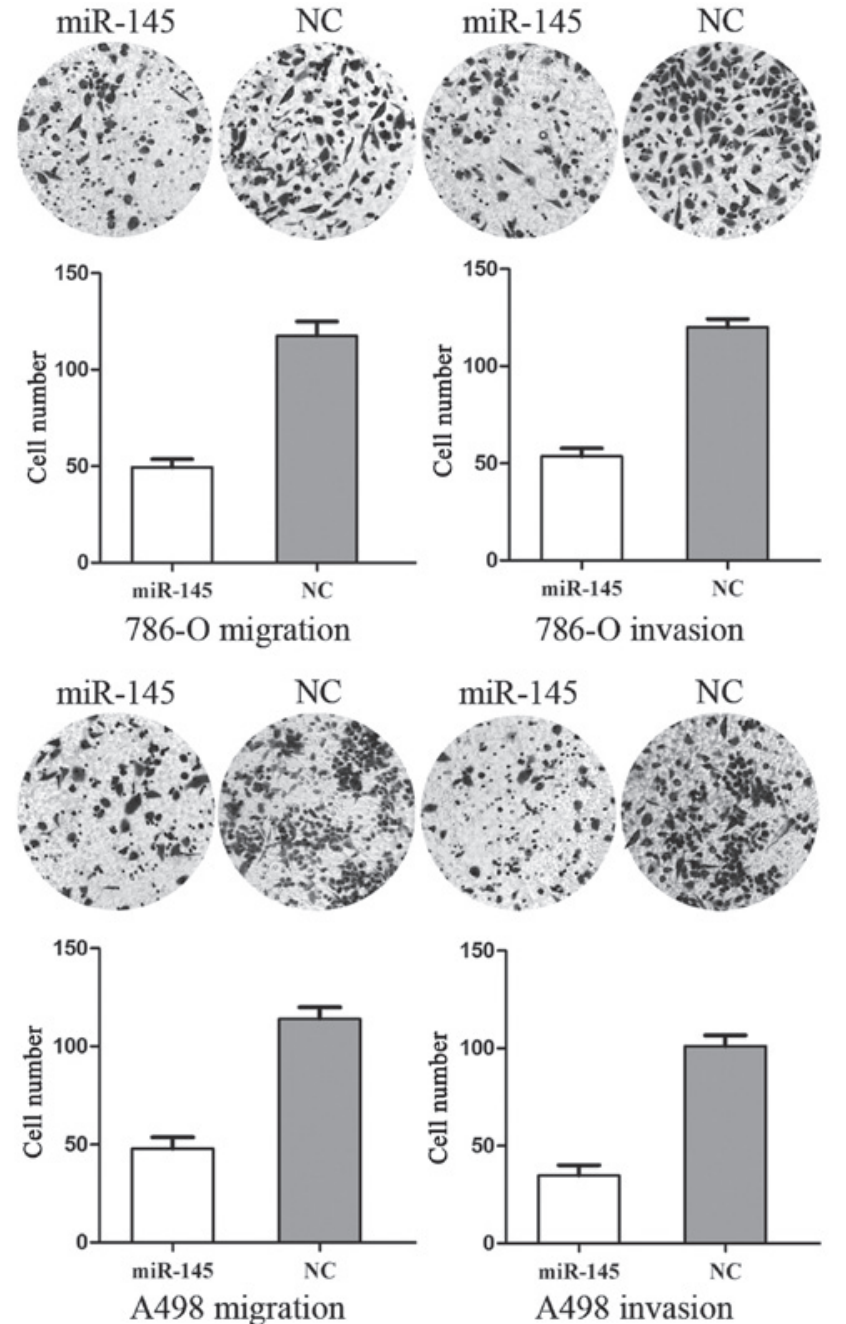

Figure 2. miR-145 inhibited cell migration and invasion in 786-O and A498 cells. Following $12 \mathrm{~h}$ incubation, cell migration was significantly decreased in the miR-145 groups compared with the control group. Following $24 \mathrm{~h}$ incubation, miR-145 transfected cells showed significantly decreased invasiveness compared with the control cells. miR-145, microRNA-145; NC, scrambled control.

MMP-11 is a direct target of miR-145. Luciferase reporter assays were performed to evaluate whether the site was able to directly mediate the inhibition of expression. As shown in Fig. 4, the overexpression of miR-145 was able to suppress MMP-11 3'UTR-luciferase activity by $57 \%$ in $786-O$ cells and $45 \%$ in A498 cells $(\mathrm{P}<0.05)$. Therefore, MMP-11 may be a direct target of miR-145 in vitro.

\section{Discussion}

miR-145 was initially identified in mice from heart tissues using small RNA cloning techniques and then later reported in humans, revealing a unique seed sequence that is conserved in Xenopus and mammals (20). Human miR-145 (hsa-miR-145) is enriched in germline and mesoderm-derived tissues, including in the uterus, ovary, testis, prostate, spleen and heart (21). It is located on chromosome 5 (5q32-33) within a $4.09 \mathrm{~kb}$ region. The first study regarding the downregulation of miR-145 in various types of tumor was conducted by Michael et al (22). The authors demonstrated that the total number of clones 


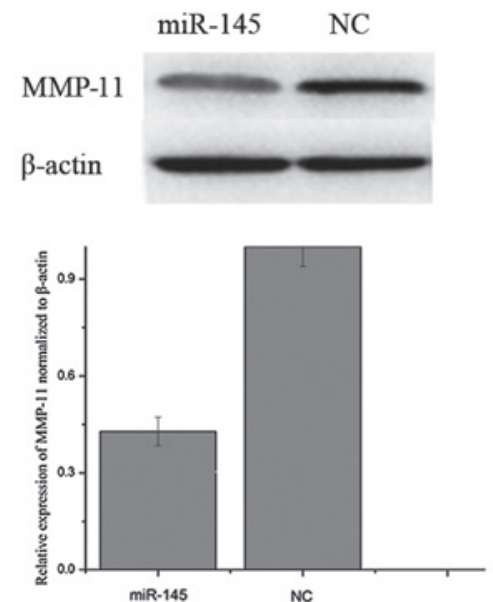

$786-\mathrm{O}$

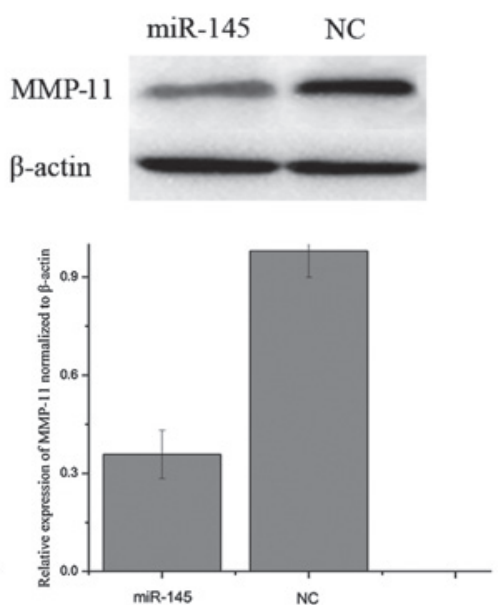

A498

Figure 3. MMP-11 was significantly decreased in 786-O and A498 cells following the transfection of miR-145. MMP-11, matrix metallopeptidase-11; miR-145, microRNA-145; NC, scrambled control.
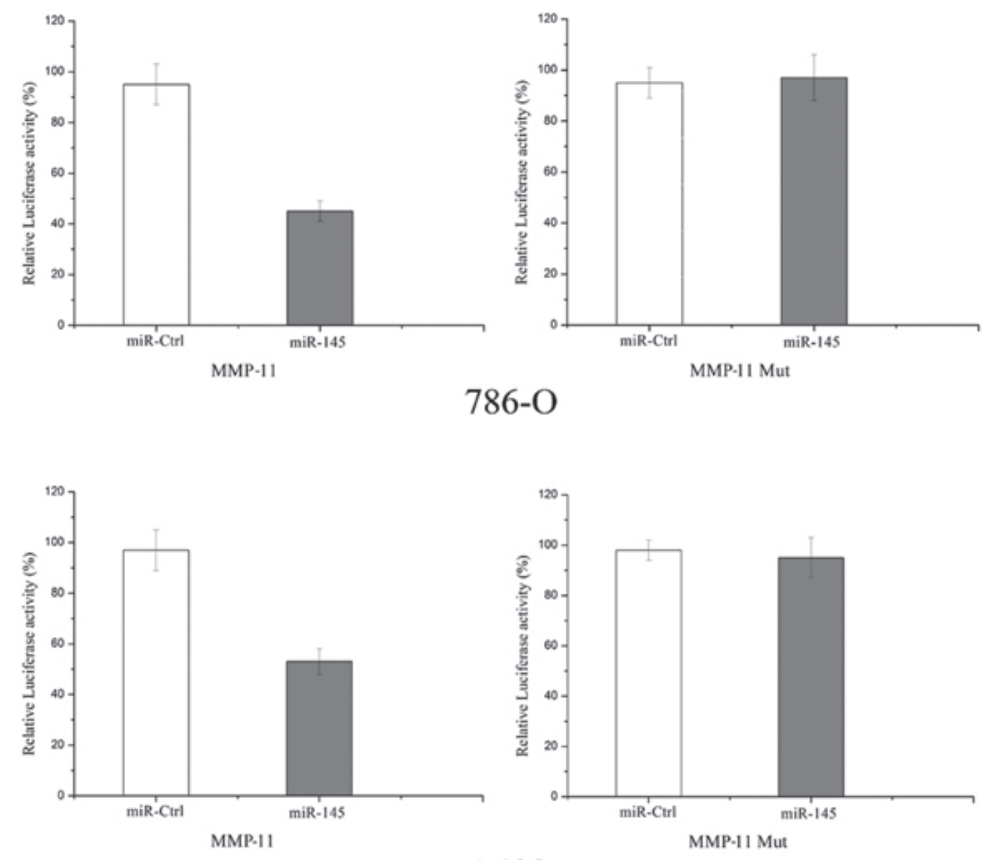

A498

Figure 4. MMP-11 may be a direct target of miR-145 in vitro. Luciferase activity significantly decreased following cotransfection with miR-145 and the reporter plasmid in 786-O and A498 cells. Overexpression of miR-145 was able to suppress MMP-11 3' untranslated region-luciferase activity by 57\% in 786-O cells and 45\% in A498 cells. MMP-11, matrix metallopeptidase-11; miR-145, microRNA-145.

sequenced for miR-145 was two from patients with colon adenocarcinomas compared with eight from normal tissue using the small RNA cloning approach. The results were confirmed by northern blot analysis. Notably, the authors also found a decreased level of miR-145 in precancerous adenomatous polyps, suggesting a possible role in tumor initiation.

miR-145 has been reported to be frequently downregulated in various types of cancer, including renal, prostate, bladder, lung and colon cancer, as well as B-cell malignancies (23-27). The identification of miR-145 target genes is critical for understanding its role in tumorigenesis and is important for defining novel therapeutic targets. miR-145 suppresses tumor cell growth by targeting insulin receptor substrate-1 (28), c-Myc (29) and several other genes associated with carcinogenesis (19). miR-145 impacts migration, invasion and metastasis by targeting Fli 1 (30) and mucin 1 (31), respectively, and also affects p53-mediated cell cycle arrest by targeting p21 (32). In addition, the downregulation of miR-145 is associated with an aggressive phenotype and poor prognosis in prostate cancer $(33,34)$. Therefore, upregulating miR-145 or providing analogous pharmaceutical compounds exogenously, may be effective cancer therapies for several types of tumor resulting from the activation or overexpression of these oncogenes. The present study revealed that miR-145 reduced cell migration and invasion by downregulating the expression of MMP-11. The results suggested that miR-145 may be used for 
the development of novel molecular markers and therapeutic approaches to inhibit the metastasis of RCC.

Metastasis is a multi-step process that requires cancer cells to detach from the main tumor, migrate and invade through the stroma, intravasate, survive in the circulatory system, arrive at a secondary site and extravasate, invade and grow at the secondary site (35). MMPs have been previously shown to contribute to migration and invasion in various types of cancer. They are a family of zinc-dependent extracellular endoproteinases that are collectively capable of degrading essentially all components of the extracellular matrix and basement membrane (36). They regulate and shape the tumor microenvironment, and are synthesized and secreted by multiple cell types, including corneal epithelial cells and fibroblasts (37). To date, at least 24 different human MMPs have been identified and they can be classified into five groups on the basis of substrate specificity, including interstitial collagenases, gelatinases, stromelysins, matrilysins and membrane-type MMPs $(38,39)$.

MMPs are found in normal and pathological tissues in which matrix remodeling is involved, including embryonic development, wound healing, arthritis and angiogenesis, as well as tumor invasion and metastasis (40). Therefore, elevated levels of MMPs have been detected in the serum and urine of patients with several different types of cancer, including cancer of the bladder, breast, lung, colon, head and neck as well as melanoma (41). These MMPs are secreted as inactive zymogens (pro-MMPs) requiring extracellular activation and their activity is tightly regulated by specific tissue inhibitors (42). In view of the important role in tumor invasion and metastasis, inhibitors of MMP activity have been investigated as a method of preventing/decreasing tumor spread.

MMP-11, also termed stromelysin-3, is encoded by the MMP11 gene located on chromosome 22 q11.23 (43). It was originally identified by screening a breast cancer cDNA library for genes that were expressed at higher levels in invasive carcinomas compared with breast fibroadenomas (44). Additional investigation has demonstrated that MMP-11 is usually overexpressed in numerous types of human carcinoma, including breast, non-small cell lung and colorectal carcinomas, however, is rarely expressed in normal tissue, including the normal tissue surrounding the tumor. Notably, only adults have been shown to express MMP-11 in tumors and regenerating or healing tissues (45-47). The functions of MMP-11 in cancer progression have been demonstrated by several preclinical observations. The upregulated expression of MMP-11 enhances tumor incidence in mice (48), homing of malignant epithelial cells (49), cancer progression by remodeling extracellular matrix (50) and has antiapoptotic and antinecrotic effects on tumor cells $(51,52)$. MMP-11 deficiency increases tumor-free survival rate and modulates local or distant invasion (53). The knockdown of MMP-11 mRNA in gastric cancer cells suppresses tumor growth in vitro and in vivo and inhibits the spread of murine hepatocarcinoma cells to lymph nodes (53). The levels of MMP-11 expression may serve as a marker for transformation and invasion in several types of cancer, otherwise, it may be a target for cancer therapy in order to inhibit metastasis. The results from the present study suggested that miR-145 suppressed the migration and invasion of RCC cells through the downregulation of MMP-11. It may be investigated as a predictive marker for the early detection of tumor metas- tasis and for targeting therapeutic drugs to inhibit the invasion of RCC.

In conclusion, to the best of our knowledge this is the first study to demonstrate that miR-145 inhibited RCC cell migration and invasion by downregulating the expression of MMP-11. These findings have therapeutic implications and may be exploited for further treatment of RCC.

Future investigation is required to address whether the potential of miR-145 may be fully realized in cancer treatment. If so, it may be beneficial for the treatment of RCC.

\section{References}

1. Siegel R, Ward E, Brawley O and Jemal A: Cancer statistics, 2011: the impact of eliminating socioeconomic and racial disparities on premature cancer deaths. CA Cancer J Clin 61: 212-236, 2011.

2. Siegel R, DeSantis C, Virgo K, Stein K, Mariotto A, Smith T, Cooper D, Gansler T, Lerro C, Fedewa S, et al: Cancer treatment and survivorship statistics, 2012. CA Cancer J Clin 62: 220-241, 2012.

3. Ferlay J, Shin HR, Bray F, Forman D, Mathers C and Parkin DM: Estimates of worldwide burden of cancer in 2008: GLOBOCAN 2008. Int J Cancer 127: 2893-2917, 2010.

4. Siegel R, Naishadham D and Jemal A: Cancer statistics, 2013. CA Cancer J Clin 63: 11-30, 2013.

5. Yan BC, Mackinnon AC and Al-Ahmadie HA: Recent developments in the pathology of renal tumors: morphology and molecular characteristics of select entities. Arch Pathol Lab Med 133: 1026-1032, 2009.

6. Yu ZH, Zhang Q, Wang YD, Chen J, Jiang ZM, Shi M, Guo X, Qin J, Cui GH, Cai ZM, et al: Overexpression of cyclooxygenase-1 correlates with poor prognosis in renal cell carcinoma. Asian Pac J Cancer Prev 14: 3729-3734, 2013.

7. Jemal A, Siegel R, Ward E, Hao Y, Xu J and Thun MJ: Cancer statistics, 2009. CA Cancer J Clin 59: 225-249, 2009.

8. Zisman A, Pantuck AJ, Wieder J, Chao DH, Dorey F, Said JW, deKernion JB, Figlin RA and Belldegrun AS: Risk group assessment and clinical outcome algorithm to predict the natural history of patients with surgically resected renal cell carcinoma. J Clin Oncol 20: 4559-4566, 2002.

9. Xue YJ, Xiao RH, Long DZ, Zou XF, Wang XN, Zhang GX, Yuan YH, Wu GQ, Yang J, Wu YT, et al: Overexpression of FoxM1 is associated with tumor progression in patients with clear cell renal cell carcinoma. J Transl Med 10: 200, 2012.

10. Choi YD, Kim KS, Ryu S, Park Y, Cho NH, Rha SH, Jang JJ, Ro JY, Juhng SW and Choi C: Claudin-7 is highly expressed in chromophobe renal cell carcinoma and renal oncocytoma. J Korean Med Sci 22: 305-310, 2007.

11. Garzon R, Pichiorri F, Palumbo T, Visentini M, Aqeilan R, Cimmino A, Wang H, Sun H, Volinia S, Alder H, et al: MicroRNA gene expression during retinoic acid-induced differentiation of human acute promyelocytic leukemia. Oncogene 26: 4148-4157, 2007.

12. Yao Y, Charlesworth J, Nair V and Watson M: MicroRNA expression profiles in avian haemopoietic cells. Front Genet 4: $153,2013$.

13. Lewis BP, Burge CB and Bartel DP: Conserved seed pairing, often flanked by adenosines, indicates that thousands of human genes are microRNA targets. Cell 120: 15-20, 2005.

14. Esquela-Kerscher A and Slack FJ: Oncomirs - microRNAs with a role in cancer. Nat Rev Cancer 6: 259-269, 2006.

15. Calin GA and Croce CM: MicroRNA signatures in human cancers. Nat Rev Cancer 6: 857-866, 2006.

16. Yoo AS,StaahlBT, ChenLand Crabtree GR: MicroRNA-mediated switching of chromatin-remodelling complexes in neural development. Nature 460: 642-646, 2009.

17. le Sage C, Nagel R, Egan DA, Schrier M, Mesman E, Mangiola A, Anile C, Maira G, Mercatelli N, Ciafrè SA, et al: Regulation of the p27(Kip1) tumor suppressor by miR-221 and miR-222 promotes cancer cell proliferation. EMBO J 26: 3699-3708, 2007.

18. Zhang H, Li Y and Lai M: The microRNA network and tumor metastasis. Oncogene 29: 937-948, 2010.

19. Sachdeva M and Mo YY: miR-145-mediated suppression of cell growth, invasion and metastasis. Am J Transl Res 2: 170-180, 2010.

20. Lagos-Quintana M, Rauhut R, Lendeckel W and Tuschl T: Identification of novel genes coding for small expressed RNAs. Science 294: 853-858, 2001. 
21. Lakshmipathy U, Love B, Adams C, Thyagarajan B and Chesnut JD: Micro RNA profiling: an easy and rapid method to screen and characterize stem cell populations. Methods Mol Biol 407: 97-114, 2007.

22. Michael MZ, O' Connor SM, van Holst Pellekaan NG, Young GP and James RJ: Reduced accumulation of specific microRNAs in colorectal neoplasia. Mol Cancer Res 1: 882-891, 2003.

23. Doberstein K, Steinmeyer N, Hartmetz AK, Eberhardt W, Mittelbronn M, Harter PN, Juengel E, Blaheta R, Pfeilschifter J and Gutwein P: MicroRNA-145 targets the metalloprotease ADAM17 and is suppressed in renal cell carcinoma patients. Neoplasia 15: 218-230, 2013.

24. Ozen M, Creighton CJ, Ozdemir M and Ittmann M: Widespread deregulation of microRNA expression in human prostate cancer. Oncogene 27: 1788-1793, 2008.

25. Ichimi T, Enokida H, Okuno Y, Kunimoto R, Chiyomaru T, Kawamoto K, Kawahara K, Toki K, Kawakami K, Nishiyama K, et al: Identification of novel microRNA targets based on microRNA signatures in bladder cancer. Int J Cancer 125: 345-352, 2009

26. Akao Y, Nakagawa Y and Naoe T: MicroRNA-143 and -145 in colon cancer. DNA Cell Biol 26: 311-320, 2007.

27. Akao Y, Nakagawa Y, Kitade Y, Kinoshita T and Naoe T: Downregulation of microRNAs-143 and -145 in B-cell malignancies. Cancer Sci 98: 1914-1920, 2007.

28. Shi B, Sepp-Lorenzino L, Prisco M, Linsley P, deAngelis T and Baserga R: Micro RNA 145 targets the insulin receptor substrate-1 and inhibits the growth of colon cancer cells. J Biol Chem 282: 32582-32590, 2007

29. Sachdeva M, Zhu S, Wu F, Wu H, Walia V, Kumar S, Elble R, Watabe K and Mo YY: p53 represses c-Myc through induction of the tumor suppressor miR-145. Proc Natl Acad Sci USA 106: 3207-3212, 2009.

30. Larsson E, Fredlund Fuchs P, Heldin J, Barkefors I, Bondjers C, Genové G, Arrondel C, Gerwins P, Kurschat C, Schermer B, et al: Discovery of microvascular miRNAs using public gene expression data: miR-145 is expressed in pericytes and is a regulator of Fli1. Genome Med 1: 108, 2009.

31. Sachdeva M and Mo YY: MicroRNA-145 suppresses cell invasion and metastasis by directly targeting mucin 1 . Cance Res 70: 378-387, 2010.

32. Seoane J, Le HV and Massagué J: Myc suppression of the p21(Cip1) Cdk inhibitor influences the outcome of the p53 response to DNA damage. Nature 419: 729-734, 2002.

33. Wang L, Tang H, Thayanithy V, Subramanian S, Oberg AL, Cunningham JM, Cerhan JR, Steer CJ and Thibodeau SN: Gene networks and microRNAs implicated in aggressive prostate cancer. Cancer Res 69: 9490-9497, 2009.

34. Chen X, Gong J, Zeng H, Chen N, Huang R, Huang Y, Nie L, Xu M, Xia J, Zhao F, et al: MicroRNA145 targets BNIP3 and suppresses prostate cancer progression. Cancer Res 70 2728-2738, 2010

35. Kwon YJ, Hurst DR, Steg AD, Yuan K, Vaidya KS, Welch DR and Frost AR: Gli1 enhances migration and invasion via up-regulation of MMP-11 and promotes metastasis in ERalpha negative breast cancer cell lines. Clin Exp Metastasis 28: 437-449, 2011.

36. Yan D, Dai H and Liu JW: Serum levels of MMP-11 correlate with clinical outcome in Chinese patients with advanced gastric adenocarcinoma. BMC Cancer 11: 151, 2011.

37. Li DQ, Shang TY, Kim HS, Solomon A, Lokeshwar BL and Pflugfelder SC: Regulated expression of collagenases MMP-1, -8, and -13 and stromelysins MMP-3, -10 , and -11 by human corneal epithelial cells. Invest Ophthalmol Vis Sci 44: 2928-2936, 2003.
38. Kähäri VM and Saarialho-Kere U: Matrix metalloproteinases and their inhibitors in tumour growth and invasion. Ann Med 31: 34-45, 1999.

39. Clark AF: New discoveries on the roles of matrix metalloproteinases in ocular cell biology and pathology. Invest Ophthalmo Vis Sci 39: 2514-2516, 1998.

40. Wu D, Ding J, Wang L, Pan H, Zhou Z, Zhou J and Qu P: microRNA-125b inhibits cell migration and invasion by targeting matrix metallopeptidase 13 in bladder cancer. Oncol Lett 5 : 829-834, 2013.

41. Moses MA, Wiederschain D, Loughlin KR, Zurakowski D, Lamb CC and Freeman MR: Increased incidence of matrix metalloproteinases in urine of cancer patients. Cancer Res 58: 1395-1399, 1998

42. Egeblad M and Werb Z: New functions for the matrix metalloproteinases in cancer progression. Nat Rev Cancer 2: 161-174, 2002.

43. Valdivia A, Peralta R, Matute-González M, Garcia Cebada JM, Casasola I, Jiménez-Medrano C, Aguado-Pérez R, Villegas V, Gonzalez-Bonilla C, Manuel-Apolinar L, et al: Co-expression of metalloproteinases 11 and 12 in cervical scrapes cells from cervical precursor lesions. Int J Clin Exp Pathol 4: 674-682, 2011.

44. Pan W, Arnone M, Kendall M, Grafstrom RH, Seitz SP, Wasserman ZR and Albright CF: Identification of peptide substrates for human MMP-11 (stromelysin-3) using phage display. J Biol Chem 278: 27820-27827, 2003.

45. Rouyer N, Wolf C, Chenard MP, Rio MC, Chambon P, Bellocq JP and Basset P: Stromelysin-3 gene expression in human cancer: an overview. Invasion Metastasis 14: 269-275, 1994.

46. Kossakowska AE, Huchcroft SA, Urbanski SJ and Edwards DR Comparative analysis of the expression patterns of metalloproteinases and their inhibitors in breast neoplasia, sporadic colorectal neoplasia, pulmonary carcinomas and malignant non-Hodgkin's lymphomas in humans. Br J Cancer 73: 1401-1408, 1996.

47. Têtu B, Brisson J, Lapointe H and Bernard P: Prognostic significance of stromelysin 3 , gelatinase $\mathrm{A}$, and urokinase expression in breast cancer. Hum Pathol 29: 979-985, 1998.

48. Nöel AC, Lefebvre O, Maquoi E, VanHoorde L, Chenard MP, Mareel M, Foidart JM, Basset P and Rio MC: Stromelysin-3 expression promotes tumor take in nude mice. J Clin Invest 97: 1924-1930, 1996

49. Masson R, Lefebvre O, Noël A, Fahime ME, Chenard MP, Wendling C, Kebers F, LeMeur M, Dierich A, Foidart JM, et al: In vivo evidence that the stromelysin-3 metalloproteinase contributes in a paracrine manner to epithelial cell malignancy. J Cell Biol 140: 1535-1541, 1998

50. Noël A, Boulay A, Kebers F, Kannan R, Hajitou A, Calberg-Bacq CM, Basset P, Rio MC and Foidart JM: Demonstration in vivo that stromelysin-3 functions through its proteolytic activity. Oncogene 19: 1605-1612, 2000.

51. Boulay A, Masson R, Chenard MP, El Fahime M, Cassard L, Bellocq JP, Sautès-Fridman C, Basset P and Rio MC: High cancer cell death in syngeneic tumors developed in host mice deficient for the stromelysin-3 matrix metalloproteinase. Cancer Res 61: 2189-2193, 2001.

52. Wu E, Mari BP, Wang F, Anderson IC, Sunday ME and Shipp MA: Stromelysin-3 suppresses tumor cell apoptosis in a murine model. J Cell Biochem 82: 549-555, 2001.

53. Peruzzi D, Mori F, Conforti A, Lazzaro D, De Rinaldis E, Ciliberto G, La Monica N and Aurisicchio L: MMP11: a novel target antigen for cancer immunotherapy. Clin Cancer Res 15: 4104-4113, 2009. 